International Journal of Heritage, Tourism and Hospitality Vol. (13), No. (1), March, 2019

By: Faculty of Tourism and Hotels, Fayoum University

\title{
The Economics of the Egyptian Stock Market and the Financing of Tourism and Hospitality Projects: A Comparative Study of some Arab Stock Markets
}

\author{
Sayed Darwish Elgarhy Mohamed Abou-Shouk Hanaa Fayed
}

Faculty of Tourism and Hotels, Fayoum University

\begin{abstract}
Stock Markets are an important part of the economics of the Arabian countries. Securities traded on a stock exchange include stock issued by listed firms and bonds. The current study aims to investigate the effect of Stock Split on Market Capitalization and Market Value in Hospitality and Tourism in three Bourses. For the purpose of the study, determinations of whether Stock Split made by Hospitality and Tourism Sector Index's firms on the Egyptian Exchange, Saudi Arabian Stock Exchange and Bahrain Bourse have an effect on the splitting firms. The study uses historical quantitative data during the period (2010:2018) collected from (ASMs). Based on linear regression analysis, the findings in Travel and Leisure Index in The Egyptian Exchange indicated that there is a significant positive relationship effect of Stock Split on Market Capitalization, Market Value, and Market Value on Market Capitalization. Furthermore, the results showed that in Tourism and Hotels index in Saudi Arabian Stock Exchange there is a significant positive relationship effect of Stock Split on Market Capitalization, Market Value, and Market Value on Market Capitalization. In addition, the results showed that in Hotels and Tourism in Bahrain Bourse there is a significant positive relationship between of Stock Split on Market Capitalization, Market Value, and Market Value on Market Capitalization. The results also revealed that Stock Split on Market Capitalization, Market Value, and Market Value on Market Capitalization was considered the most criterion validity in the three Bourses.
\end{abstract}

Keywords: Arabian Stock Markets (ASMs), Travel \& Leisure Sector Index, Finance, Investment, Hospitality \& Tourism Projects, Stock Split, Market Value, Market Capitalization.

\section{Introduction}

Stock Markets are playing a vital role the economics of the Arabian countries. Tourism industry needs finance to meet their requirements in hospitality and tourism projects. Any kind of tourism projects depends on the finance. Hence, it is called as lifeblood of tourism establishments management boards finance their projects such as hospitality and tourism projects in Hospitality and Tourism Index's in Arabian Stock Markets (ASMs). When people draw their savings and invest in shares through an Initial Public Offering of the issuance of new firm shares of an already listed firm, which could have been consumed, or kept it idle deposits with banks, are mobilized and redirected to help firms management boards finance their projects such as hospitality and tourism projects in Travel and Leisure Sector Index in the Egyptian Exchange, Tourism and Hotels Sector Index in Saudi Arabian Stock Exchange, and Hotels and Tourism Sector Index in Bahrain Bourse. This may promote business activity with benefits for several economic sectors (Barrows \& Naka, 1994; Chen et al., 2005; Chen, 2007b; Borghesi et al, 2015). A stock exchange is often the most important component of a stock market. Demand and supply in stock markets are driven by various factors that, as in all free markets, affect the price of stocks (Faure, 2015a; Amadeo, 2016). In practical business life, investment and the finance of investments are very often closely connected. However even though investments cannot be carried out without finance, they are often not connected in such a way that investment and finance are linked together as a package (Petersen, 2017). Hospitality and Tourism Sector Index's in all Stock Markets in the world are heavy users of long-term debt to support their asset investment and growth opportunities, and the debt structure is comprised largely of fixed-rate 
debt, for example Sporting Clubs, Casinos, Resorts, Hotels, and Restaurants (Steve Pan \& Lee, 2011). The goal of hospitality and tourism firm's existence in (ASMs) i.e.: The Egyptian Exchange, Saudi Arabian Stock Exchange, and Bahrain Bourse, is to maximize its owner's wealth. To achieve this goal, hospitality and tourism firms have to maximize their revenues by providing customers with satisfactory services and products; meantime, they need to minimize costs. Three parties are involved in hospitality and tourism firm's operation: the customer who consumes services and products, the producer who provides services and products, and the investor who provides the capital needed for the operation (Park \& Jang, 2014; Jang \& Park, 2011; Tasi et al., 2011). Hospitality stock returns can be considered as one of the most significant changes in the global stock exchange increasing globalization of the world economy was the engine of this movement (Nicolau \& Santa-Maria, 2013). This study focused on hospitality and tourism returns in the (ASMs), and have the superfluous role to play in the businesses and economics of the Egyptian Stock Market, Saudi Arabia Stock Exchange and Bahrain Bourse (Eltony \& Babiker, 2005). According to (EGX, Tadawul, and Bahrain Bourse Reports, 2017) The Egyptian Exchange, Saudi Arabian Stock Exchange, and Bahrain Bourse, Stock Markets consist of many sectors i.e.: Telecommunications Basic Resources, Personal and Household Products, Media and Publishing, Transport, Cement, Retail Estate, Banks and Financial Services, Energy and Utilities, Industrial Services Excluding Banks, Real Estate Development, Healthcare \& Pharmaceuticals Insurance, Agriculture and Food, Building \& Construction, Multi-investment, Industrial Investment, Hospitality and Tourism, Petrochemicals, Commercial Banks, and Telecom and Information Technology. The main reason is to choose three Bourses from the (ASMs). Because some Arabian Stock Markets do not list firms or Hospitality and Tourism Sector Indexes such as: Qatar Exchange, Bourse de Tunis, Palestine Securities Exchange, and Iraq Stock Exchange. But in the selected three bourses there are travel and leisure Sector Index in the Egyptian Exchange, Tourism and Hotels Sector Index in Saudi Arabian Stock Exchange, and Hotels and Tourism Sector Index in Bahrain Bourse. The objective of this research is to analyze the effect of stock Split adoption send positive or negative signals to market players specifically, Market Capitalization, Market Value, and the investors in hospitality and tourism stock returns.

\section{Research Framework}

To test the relationship between Stock Split adoption in Hospitality and Tourism Index's in the Egyptian Exchange, Saudi Arabian Stock Exchange, and Bahrain Bourse, as independent variable, and the (Market Capitalization and Market Value) as dependent variables.

Figure 1: Rresearch model including the main constructs of the study

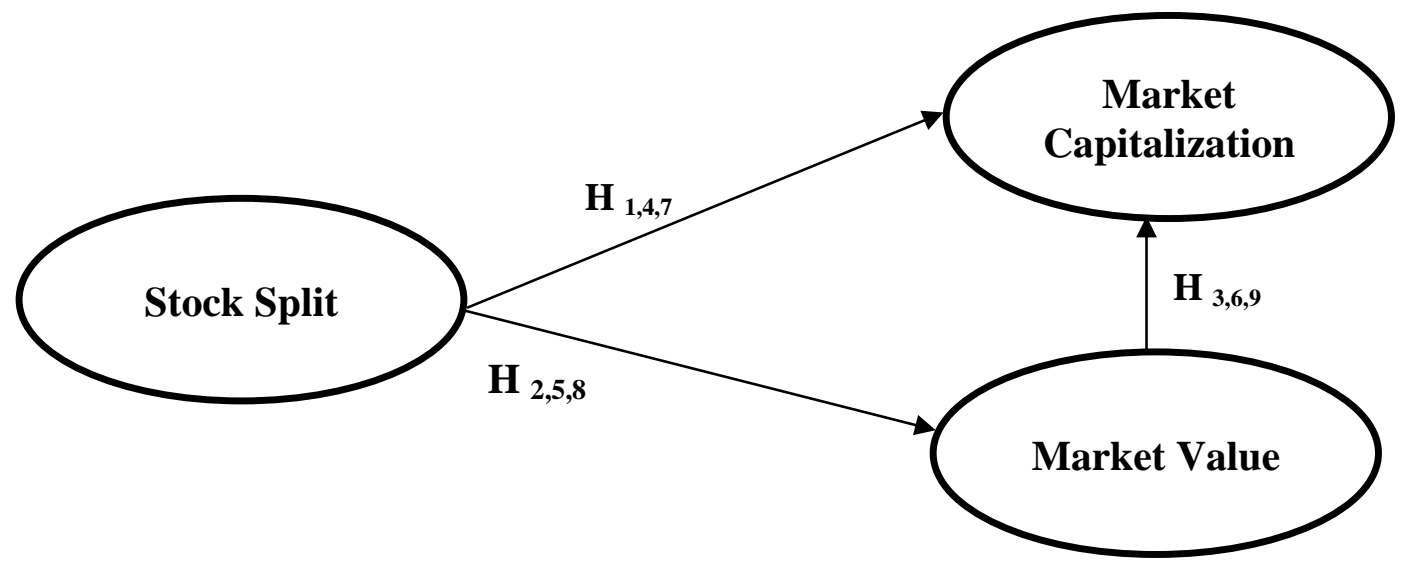




\section{Limitation of study}

The analysis is limited to the availability of the recorded data in (ASMs) in Hospitality and Tourism Sector Index's in The Egyptian Exchange, Saudi Arabian Stock Exchange, and Bahrain Bourse during the period (2010 to 2018). The main reason is to choose three Bourses from the (ASMs). Because in the selected three bourses there are Travel and Leisure Sector Index in the Egyptian Exchange, Tourism and Hotels Sector Index in Saudi Arabian Stock Exchange, and Hotels and Tourism Sector Index in Bahrain Bourse.

\section{Development of research hypothesis}

Stock splits have been investigated by academic researchers from different countries. Some focused on the reasons why firms declare stock splits. Some investigated the stock price behavior around stock split in different stocks markets and increasing the market capitalization of a firm's stock is also another reason behind stock split. That is, when the stock price is low the stock becomes more liquid. For these reasons a firm may decide to declare stock split. According to (Agara, 2014), In Nairobi Securities Exchange, the study found that there is a significant positive relationship between effects of Stock Split and Share prices for companies listed at the Nairobi Securities Exchange during the period (2009 to 2013) with a sample size of 7 firms. And hence recommends that Capital Market Authority reviews the policy on this event to encourage firms to adopt stock splitting, educate the public on the operations at the Nairobi Stock Exchange to reduce abnormal reaction of prices caused by speculative retail trading. This will be in a bid to encourage more long-term investments than short-term ones as well as impart knowledge on the public regarding stock market activity. Furthermore, Tabibian (2013), in Malaysia investigated the effect of Stock Split on Stock return among firms that did forward Stock Split in Bourse Malaysia during the period (2010 to 2011). He found a significant positive effect of Stock Splits on Stock Returns Around both announcement day (1.386\%) and Ex-date (1.137\%). On the other hand, Bandyopadhyay et al., (2010), reported a study conducted in USA, to examine the influence of share splits for 12 IShare Exchange-Traded Funds (ETFs) issued by Barclay Global Investors. They found that there are increases in spreads and frequency of small trades and the decrease in average trade size experienced by the split IShares that are consistent with the brokerpromotion hypothesis, while there is a significant increase in daily turnover after the split that is consistent with the trading-inconvenience hypothesis. Neither hypothesis is supported by the trade-price location parameter or by trade imbalance in the post-split period. This suggests that stock splits, being anticipated events, allow market makers and small investors to be able to predict order flows and adjust their positions accordingly. Huang et al., (2011), Waweru et al., (2012); Nyaga, (2017), in Nairobi Stock Market in Kenya. El Ansary and Hussien (2017) in Egyptian Stock Market. These studies found that there is a positive significant relationship between effects of the Stock Splits on Share Prices. On the other hand, the significance of the effect of Stock Split decreases as the Market Capitalization of the firm increases. In other words, the positive impact of the Stock Split is more significant for small Market Capitalization firms. Chowdhury (2014), in USA examined an empirical investigation in U.S. technology sector during the period (1995-2013). The findings indicate a significant effect of Stock Split announcements on prices of U.S. High Technology stocks. Furthermore, Abdolmohammadi (2005) in the USA, Orens et al., (2009) in continental European countries Abeysekera (2011) in Sri Lanka, and Anam et al., (2011) in Malaysia. These studies found that there is a positive significant relationship between Intellectual Capital disclosure on Market Capitalization and Market Value. The argument underlining such a relationship is that when there are Intellectual 
Capital related activities, it would be a significant part of a company's values. Thus, these values contribute to the Market Capitalization of the company. As a result, a company would expect to report these values with more Intellectual Capital disclosure to explain their effects on Market Capitalization and Market Value. Thus, the current study can be considered the first to test the relationship between effect of Stock split on Market Capitalization, Market Value, and Market Value on Market Capitalization in hospitality and tourism sector Index's in three Bourses the Egyptian Exchange, Saudi Arabian Stock Exchange, and Bahrain Bourse. Consequently, it is hoped that a study in this area would produce findings that are beneficial, while simultaneously filling the gap in the (ASMs).

\section{Therefore, nine main hypotheses were developed in this study}

$\mathrm{H}_{1}$ There is a significant effect of Stock Split adoption on Market Capitalization in Travel and Leisure Sector Index in the Egyptian Exchange.

$\mathrm{H}_{2}$ There is a significant effect of Stock Split adoption on Market Value in Travel and Leisure Sector Index in the Egyptian Exchange.

$\mathrm{H}_{3}$ There is a significant effect of Market Value adoption on Market Capitalization in Travel and Leisure Sector Index in the Egyptian Exchange.

$\mathrm{H}_{4}$ There is a significant effect of Stock Split adoption on Market Capitalization in Tourism and Hotels Sector Index in Saudi Arabian Stock Exchange.

$\mathrm{H}_{5}$ There is a significant effect of Stock Split adoption on Market Value in Tourism and Hotels Sector Index in Saudi Arabian Stock Exchange.

$\mathrm{H}_{6}$ There is a significant effect of Market Value adoption on Market Capitalization in Tourism and Hotels Sector Index in Saudi Arabian Stock Exchange.

H7 There is a significant effect of Stock Split adoption on Market Capitalization in Hotels and Tourism Sector Index in Bahrain Bourse.

$\mathrm{H}_{8}$ There is a significant effect of Stock Split adoption on Market Value in Hotels and Tourism Sector Index in Bahrain Bourse.

$\mathrm{H}_{9}$ There is a significant effect of Market Value adoption on Market Capitalization in in Hotels and Tourism Sector Index in Bahrain Bourse.

\section{Research Methodology}

The current study uses historical quantitative data within the period (2010 to 2018) collected from (ASMs), Egyptian Exchange, Saudi Arabian Stock Exchange, Bahrain Bourse, EGX Annual Reports, Tadawul Annual Reports, Bahrain Annual Reports, and Financial Statements to follow the deductive approach, to test the study hypotheses and accomplish its objectives (Trzesniewski et al., 2011: Vartanian, 2011). Data collected were coded and analyzed using statistical package for social sciences (SPSS), version 23. under windows 7. Simple descriptive analysis in the form of percentage distribution, Means, Simple Linear Regression, R Square, were done. However, suitable inferential statistics was done to test the level of significance with a confidence level of 0.05 (Thomas and Heck, 2001: Spagat and Dougherty, 2010).

\section{The population and data periods covered}

The study population includes firms which took the Stock Split in the Hospitality and Tourism Sector Index's in the Egyptian Exchange, Saudi Arabian Stock Exchange, and Bahrain Bourse. The study depends on the secondary data collected from the period from (2010 to 2018) in the Arabian Stock Markets (ASMs). For the Egyptian Stock Market, Travel and Leisure Sector Index 
includes 16 firms i.e.: El Shams Pyramids for Hotels \& Touristic Projects, Remco for Touristic Villages Construction, Orascom Development Egypt, Rowad Misr Tourism Investment, Egyptian International Tourism Projects, Rowad Tourism (Al Rowad), Golden Pyramids Plaza, Pyramisa Hotels, Egyptian for Tourism Resorts, Egyptian for Tourism Resorts, Misr Hotels, Sky Light For Tourist Development Company, Marsa Marsa Alam For Tourism Development, Golden Coast Company, and Sharm Dreams Co. for Tourism Investment (EGX Annual Report, 2018; El Garhy et al., 2017). It is noteworthy, firms were excluded like: Remco for Touristic Villages Construction, Orascom Development Egypt, Rowad Misr Tourism Investment, Trans Oceans Tours, Golden Pyramids Plaza, Pyramisa Hotels, Egyptian for Tourism Resorts, and Sky Light for Tourist Development Company. The reason for this non splitting firms. For the Saudi Arabian Stock Exchange, Tourism and Hotels Sector Index includes 6 firms i.e.: Altayyar Travel Group, Abdul Mohsen Alhokair Group for Tourism \& Development, Dur Hospitality Co., Tourism Enterprise Co., Alkhaleej Training and Education Co., Herfy Food Services Co (Tadawul Annual Report, 2018). It is noteworthy, firms were excluded like: Abdul Mohsen Alhokair Group for Tourism \& Development, Dur Hospitality Co., and Tourism Enterprise Co. (Shams). The reason for this non splitting firms. For Bahrain Bourse, Hotels and Tourism Sector Index includes 4 firms i.e.: Bahrain Family Leisure, Banader Hotels Company BSC, Gulf Hotel Group B.S.C., and National Hotels Company (Bahrain Bourse Annual Report, 2018). It is noteworthy, firms were excluded like: Banader Hotels Company BSC.

\section{Hypotheses-Testing}

Test of $\mathrm{H}_{1}$ There is a significant effect of Stock Split adoption on Market Capitalization in Travel and Leisure Index in the Egyptian Exchange.

Table 1: Egyptian Exchange percentage exchange between (Stock Split - Market Capitalization) for Travel and Leisure Index Firms during the Period 2010: 2018

\begin{tabular}{|c|c|c|c|c|c|c|}
\hline Travel and Leisure Index firms & $\begin{array}{c}\text { Shares } \\
2010\end{array}$ & $\begin{array}{c}\text { Shares } \\
2018\end{array}$ & $\begin{array}{c}\%(2010: \\
2018)\end{array}$ & $\begin{array}{c}\text { Market } \\
\text { Cap 2010 }\end{array}$ & $\begin{array}{c}\text { Market Cap } \\
2018\end{array}$ & $\begin{array}{c}\%(2010 \\
: 2018)\end{array}$ \\
\hline $\begin{array}{c}\text { El Shams Pyramids For Hotels \& } \\
\text { Touristic Projects }\end{array}$ & 5999321 & 47000000 & $683 \%$ & 11398709.9 & 140060000 & $1129 \%$ \\
\hline $\begin{array}{c}\text { El Wadi Co. For Touristic } \\
\text { Investment }\end{array}$ & 14400000 & 18200000 & $26 \%$ & 14400000 & 1450540000 & $9973 \%$ \\
\hline Rowad Tourism (Al Rowad) & 3142067 & 17311800 & $451 \%$ & 40501244 & 174156708 & $330 \%$ \\
\hline Misr Hotels & 3300000 & 13200000 & $300 \%$ & 118470000 & 682440000 & $476 \%$ \\
\hline $\begin{array}{c}\text { Marsa Marsa Alam For Tourism } \\
\text { Development }\end{array}$ & 20000000 & 50000000 & $150 \%$ & 20000000 & 50000000 & $150 \%$ \\
\hline $\begin{array}{c}\text { Egyptian International Tourism } \\
\text { Projects }\end{array}$ & 24000000 & 400000000 & $1567 \%$ & 20640000 & 1156000000 & $5501 \%$ \\
\hline Golden Coast Company & 2000000 & 10000000 & $400 \%$ & 2000000 & 54700000 & $2635 \%$ \\
\hline $\begin{array}{c}\text { Sharm Dreams Co. For Tourism } \\
\text { Investment }\end{array}$ & 45000 & 52985460 & $117645 \%$ & 463500 & 274994537 & $59230 \%$ \\
\hline
\end{tabular}

Accordingly, it turns out from table (1) that Stock Split works to increase Market Capitalization like: El Shams Pyramids for Hotels \& Touristic Projects that indicates 1129\%, El Wadi Co. For Touristic Investment that indicates 9973\%, Rowad Tourism (Al Rowad) that indicates 330\%, Misr Hotels that indicates 476\%, Marsa Marsa Alam for Tourism Development that indicates 150\%, Egyptian International Tourism Projects 5501\%, Golden Coast Company that indicates 2635\%, and Sharm Dreams Co. For Tourism Investment that indicates 59230\%. This point is supported by the study conducted by Huang et al., (2011), Waweru et al., (2012); Nyaga, (2017), 
Elgarhy et al., (2015a), Elgarhy et al., (2017b), El Ansary and Hussien (2017), Salama (2017). Which proves to us that, Stock Split works to increase Market Capitalization and encourages small investors to invest in Travel and Leisure Index. On the other hand, Stock Split attracts more investors to finance in tourism and hospitality projects and future company's investment plans.

Table 2: Egyptian Exchange between (Stock Split - Market Capitalization) results of regression analysis

\begin{tabular}{|c|c|c|c|c|c|c|}
\hline & $\mathrm{R}^{2}$ & $\mathrm{~F}$ & $\mathrm{~B}$ & Std. Error & $\mathrm{T}$ & Sig. \\
\hline Constant & .147 & 24.375 & $4.897 \mathrm{E} 8$ & $1.506 \mathrm{E} 8$ & 3.252 & .001 \\
\hline Market Capitalization & & & 2.346 & .475 & 4.937 & .000 \\
\hline
\end{tabular}

Table 2: illustrates the statistics of linear regression calculated to measure the impact of Stock Split on Market Capitalization. It is revealed that, ( $\mathrm{B}$ value $=2.346), \mathrm{P}<0.01$. A significant positive effect of Stock split on Market Capitalization was found in the Egyptian context. It is revealed that Stock Split is explaining $14.7 \%$ of Market Capitalization increase $\left(\mathrm{R}^{2}=.147\right)$. Thus, the first hypothesis is supported in the Egyptian context.

Test of $\mathrm{H}_{2}$ There is a significant effect of Stock Split adoption on Market Value in Travel and Leisure Index in the Egyptian Exchange.

Table 3: Egyptian Exchange percentage exchange between (Stock Split - Market Value Change Rate) for Travel and Leisure Index during the Period 2010:2018

\begin{tabular}{|l|c|c|c|c|}
\hline \multicolumn{1}{|c|}{ Travel and Leisure Index firms } & $\begin{array}{c}\text { Shares } \\
2010\end{array}$ & $\begin{array}{c}\text { Shares } \\
2018\end{array}$ & $\begin{array}{c}\%(2010: \\
2018)\end{array}$ & $\begin{array}{c}\text { Market Value } \\
\text { Change Rate } \% \\
(2010: 2018)\end{array}$ \\
\hline $\begin{array}{l}\text { El Shams Pyramids For Hotels \& Touristic } \\
\text { Projects }\end{array}$ & 5999321 & 47000000 & $683 \%$ & $0.32 \%$ \\
\hline El Wadi Co. For Touristic Investment & 14400000 & 18200000 & $26 \%$ & $7.65 \%$ \\
\hline Rowad Tourism (Al Rowad) & 3142067 & 17311800 & $451 \%$ & $10.9 \%$ \\
\hline Misr Hotels & 3300000 & 13200000 & $300 \%$ & $23.4 \%$ \\
\hline Marsa Marsa Alam For Tourism Development & 20000000 & 50000000 & $150 \%$ & $14.8 \%$ \\
\hline Egyptian International Tourism Projects & 24000000 & 400000000 & $1567 \%$ & $6.16 \%$ \\
\hline Golden Coast Company & 2000000 & 10000000 & $400 \%$ & $10.6 \%$ \\
\hline Sharm Dreams Co. For Tourism Investment & 45000 & 52985460 & $117645 \%$ & $8.91 \%$ \\
\hline
\end{tabular}

Accordingly, it is obvious from table (3) that Stock Split works to increase Market Value like: El Wadi Co. For Touristic Investment that indicates 7.65\%, Rowad Tourism (Al Rowad) that indicates $10.9 \%$, Misr Hotels that indicates 23.4\%, Marsa Marsa Alam for Tourism Development that indicates $14.8 \%$, Egyptian International Tourism Resorts 6.16\%, Golden Coast Company that indicates $10.6 \%$, Sharm Dreams Co. For Tourism Investment that indicates 8.91\%, Trans Oceans Tours that indicates $12.9 \%$, and Golden Pyramids Plaza that indicates $14.4 \%$. This point is supported by the study conducted by Bandyopadhyay et al., (2010); Huang et al., (2011), Waweru et al., (2012); Tabibian (2013); Agara, (2014); Chowdhury (2014); Nyaga, (2017). This proves that Stock Split works to increase Market Value and encourages investors to invest in Hotels and Tourism Index and attract more investors to finance in tourism and hospitality projects and future company's investment plan. 
International Journal of Heritage, Tourism and Hospitality Vol. (13), No. (1), March, 2019 By: Faculty of Tourism and Hotels, Fayoum University

Table 4: Egyptian Exchange between (Stock Split - Market Value) results of regression analysis

\begin{tabular}{|c|c|c|c|c|c|c|}
\hline & $\mathrm{R}^{2}$ & $\mathrm{~F}$ & $\mathrm{~B}$ & Std. Error & $\mathrm{T}$ & Sig. \\
\hline Constant & .703 & 9.451 & 1.287 & 1.254 & 1.027 & .363 \\
\hline Market Value & & & 1.619 & .526 & 3.074 & .037 \\
\hline
\end{tabular}

Table (4) illustrates the statistics of linear regression calculated to measure the impact of Stock Split on Market Value. It is revealed that, $(\mathrm{B}$ value $=1.619), \mathrm{P}<0.01$. A significant positive effect of Stock Split on Market Value was found in the Egyptian context. It is revealed that Stock Split is explaining $70.3 \%$ of Market Value increase $(\mathrm{R} 2=.703)$. Thus, the second hypothesis is supported in the Egyptian context.

\section{Test of $\mathrm{H}_{3}$ There is a significant effect of Market Value adoption on Market Capitalization in Travel and Leisure Index in the Egyptian Exchange.}

Table 5: Egyptian Exchange percentage exchange between (Market Value - Market

Capitalization) for Travel and Leisure Index Firms during the Period 2010 : 2018

\begin{tabular}{|c|c|c|c|c|}
\hline Travel and Leisure Index firms & $\begin{array}{c}\text { Market Value } \\
\text { Change Rate \% } \\
(2010: 2018)\end{array}$ & $\begin{array}{c}\text { Market } \\
\text { Capitalization } \\
2010\end{array}$ & $\begin{array}{c}\text { Market } \\
\text { Capitalization } \\
2018\end{array}$ & $\begin{array}{c}\%(2010 \\
: 2018)\end{array}$ \\
\hline $\begin{array}{c}\text { El Shams Pyramids For Hotels \& Touristic } \\
\text { Projects }\end{array}$ & $0.32 \%$ & 11398709.9 & 140060000 & $1129 \%$ \\
\hline El Wadi Co. For Touristic Investment & $7.65 \%$ & 14400000 & 1450540000 & $9973 \%$ \\
\hline Rowad Tourism (Al Rowad) & $10.9 \%$ & 40501244 & 174156708 & $330 \%$ \\
\hline Misr Hotels & $23.4 \%$ & 118470000 & 682440000 & $476 \%$ \\
\hline $\begin{array}{c}\text { Marsa Marsa Alam For Tourism } \\
\text { Development }\end{array}$ & $14.8 \%$ & 20000000 & 50000000 & $150 \%$ \\
\hline Egyptian International Tourism Projects & $6.16 \%$ & 20640000 & 1156000000 & $5501 \%$ \\
\hline Golden Coast Company & $10.6 \%$ & 2000000 & 54700000 & $2635 \%$ \\
\hline $\begin{array}{c}\text { Sharm Dreams Co. For Tourism } \\
\text { Investment }\end{array}$ & $8.91 \%$ & 463500 & 274994537 & $59230 \%$ \\
\hline
\end{tabular}

Accordingly, it turns out from table (5) that Market Value works to increase Market Capitalization like: El Shams Pyramids for Hotels \& Touristic Projects that indicates 1129\%, El Wadi Co. For Touristic Investment that indicates 9973\%, Rowad Tourism (Al Rowad) that indicates $330 \%$, Misr Hotels that indicates 476\%, Marsa Marsa Alam for Tourism Development that indicates $150 \%$, Egyptian International Tourism Projects 5501\%, Golden Coast Company that indicates 2635\%, Sharm Dreams Co. For Tourism Investment that indicates $59230 \%$. Which proves to us that, Market Value works to increase Market Capitalization and encourages small investors to invest in Travel and Leisure Index. On the other hand, Stock Split attracts more investors to finance in tourism and hospitality projects and future company's investment plans.

Table 6: Egyptian Exchange between (Market Value - Market Capitalization) results of regression analysis

\begin{tabular}{|c|c|c|c|c|c|c|}
\hline & $\mathrm{R}^{2}$ & $\mathrm{~F}$ & $\mathrm{~B}$ & Std. Error & $\mathrm{T}$ & Sig. \\
\hline Constant & .778 & 10.534 & .318 & .421 & .754 & .506 \\
\hline Market Capitalization & & & .126 & .039 & 3.246 & .048 \\
\hline
\end{tabular}


Table (6) illustrates the statistics of linear regression calculated to measure the impact of Market Value on Market Capitalization. It is revealed that, $(\mathrm{B}$ value $=.126), \mathrm{P}<0.01$. A significant positive effect of Market Value on Market Capitalization was found in the Egyptian context. It is revealed that Market Value is explaining $77.8 \%$ of Market Capitalization increase $\left(\mathrm{R}^{2}=.778\right)$. Thus, the third hypothesis is supported in the Egyptian context.

Test of $\mathrm{H}_{4}$ There is a significant effect of Stock Split adoption on Market Capitalization in Tourism and Hotels Index in Saudi Arabian Stock Exchange.

Table 7: Saudi Arabian Stock Exchange percentage exchange between (Stock Split - Market Capitalization) for Tourism and Hotels Index during the Period 2010 : 2018

\begin{tabular}{|c|c|c|c|c|c|c|}
\hline $\begin{array}{c}\text { Tourism and Hotels } \\
\text { Index firms }\end{array}$ & $\begin{array}{c}\text { Shares } \\
2010\end{array}$ & $\begin{array}{c}\text { Shares } \\
2018\end{array}$ & $\begin{array}{c}\%(2010 \\
: 2018)\end{array}$ & $\begin{array}{c}\text { Market } \\
\text { Capitalization } \\
2010\end{array}$ & $\begin{array}{c}\text { Market } \\
\text { Capitalization } \\
2018\end{array}$ & $\begin{array}{c}\% \\
(2010: \\
2018)\end{array}$ \\
\hline Altayyar Travel Group & 80000000 & 209650000 & $162 \%$ & 80000000 & 5304145000 & $6530.20 \%$ \\
\hline $\begin{array}{c}\text { Alkhaleej Training and } \\
\text { Education Co. }\end{array}$ & 15000000 & 45000000 & $200 \%$ & 202500000 & 679500000 & $235.60 \%$ \\
\hline Herfy Food Services Co. & 27000000 & 64680000 & $140 \%$ & 828900000 & 2955876000 & $256.60 \%$ \\
\hline
\end{tabular}

Accordingly, it is obvious from table (7) that Stock Split works to increase Market Capitalization like: Altayyar Travel Group that indicates 6530.2\%, Alkhaleej Training and Education Co. that indicates $235.6 \%$, and Herfy Food Services Co that indicates 256.6\%. This point is supported by the study conducted by Huang et al., (2011), Waweru et al., (2012); Nyaga, (2017), Elgarhy et al., (2015a), Elgarhy et al., (2017b), El Ansary and Hussien (2017), Salama (2017). Which proves to us that, Stock Split works to increase Market Capitalization and encourages small investors to invest in Tourism and Hotels Index and attract more investors to finance in tourism and hospitality projects and future company's investment plans.

Table 8: Saudi Arabian Stock Exchange between (Stock Split - Market Capitalization) results of Regression analysis

\begin{tabular}{|c|c|c|c|c|c|c|}
\hline & $\mathrm{R}^{2}$ & $\mathrm{~F}$ & $\mathrm{~B}$ & Std. Error & $\mathrm{T}$ & Sig. \\
\hline Constant & .082 & 4.671 & $1.526 \mathrm{E}-9$ & $5.611 \mathrm{E} 8$ & 2.720 & .009 \\
\hline Market Capitalization & & & 9.587 & 4.436 & 2.161 & .035 \\
\hline
\end{tabular}

Table (8) illustrates the statistics of linear regression calculated to measure the impact of Stock Split on Market Capitalization. It is revealed that, $(\mathrm{B}$ value $=9.587), \mathrm{P}<0.01$. A significant positive effect of Stock Split on Market Capitalization was found in the Saudi context. It is revealed that Stock Split is explaining $8.2 \%$ of Market Capitalization increase $\left(\mathrm{R}^{2}=.082\right)$. Thus, the forth hypothesis is supported in the Saudi context. 
International Journal of Heritage, Tourism and Hospitality Vol. (13), No. (1), March, 2019 By: Faculty of Tourism and Hotels, Fayoum University

Test of $\mathrm{H}_{5}$ There is a significant effect of Stock Split adoption on Market Value in Tourism and Hotels Index in Saudi Arabian Stock Exchange.

Table 9: Saudi Arabian Stock Exchange percentage exchange (Stock Split - Market Value Change Rate) for Travel and Leisure Index during the Period $2010: 2018$

\begin{tabular}{|c|c|c|c|c|}
\hline Tourism and Hotels Index firms & $\begin{array}{c}\text { Shares } \\
2010\end{array}$ & $\begin{array}{c}\text { Shares } \\
2018\end{array}$ & $\begin{array}{c}\%(2010 \\
: 2018)\end{array}$ & $\begin{array}{c}\text { Market Value } \\
\text { Change Rate } \% \\
(2010: 2018)\end{array}$ \\
\hline Altayyar Travel Group & 80000000 & 209650000 & $162 \%$ & $43.4 \%$ \\
\hline $\begin{array}{c}\text { Alkhaleej Training and Education } \\
\text { Co. }\end{array}$ & 15000000 & 45000000 & $200 \%$ & $27.9 \%$ \\
\hline Herfy Food Services Co. & 27000000 & 64680000 & $140 \%$ & $60.3 \%$ \\
\hline Tourism and Hotels Index firms & $\begin{array}{c}\text { Shares } \\
2010\end{array}$ & $\begin{array}{c}\text { Shares } \\
2018\end{array}$ & $\begin{array}{c}\%(2010 \\
: 2018)\end{array}$ & $\begin{array}{c}\text { Market Value } \\
\text { Change Rate } \% \\
(2010: 2018)\end{array}$ \\
\hline $\begin{array}{c}\text { Alkhaleej Training and Education } \\
\text { Co. }\end{array}$ & 150000000 & 209650000 & $162 \%$ & $43.4 \%$ \\
\hline Herfy Food Services Co. & 27000000 & 645000000 & $200 \%$ & $27.9 \%$ \\
\hline
\end{tabular}

Accordingly, it is obvious from table (9) that Stock Split works to increase Market Value like: Altayyar Travel Group that indicates 43.4\%, Alkhaleej Training and Education Co. that indicates 27.9\%, and Herfy Food Services Co that indicates 60.3\%. This point is supported by the study conducted by Bandyopadhyay et al., (2010); Huang et al., (2011), Waweru et al., (2012); Tabibian (2013); Agara, (2014); Chowdhury (2014); Nyaga, (2017). Which proves to us that, Stock Split works to increase Market Value and encourages investors to invest in Hotels and Tourism Index and attract more investors to finance in tourism and hospitality projects and future company's investment plans.

Table 10: Saudi Arabian Stock Exchange between (Stock Split - Market Value) results of Regression analysis

\begin{tabular}{|c|c|c|c|c|c|c|}
\hline & $\mathrm{R}^{2}$ & $\mathrm{~F}$ & $\mathrm{~B}$ & Std. Error & $\mathrm{T}$ & Sig. \\
\hline Constant & .668 & 8.063 & .073 & .018 & 1.027 & .016 \\
\hline Market Value & & & .134 & .047 & 3.074 & .047 \\
\hline
\end{tabular}

Table (10) illustrates the statistics of linear regression calculated to measure the impact of Stock Split on Market Value. It is revealed that, $(\mathrm{B}$ value $=.134), \mathrm{P}<0.01$. A significant positive effect of Stock Split on Market Value was found in the Saudi context. It is revealed that Stock Split is explaining $66.8 \%$ of Market Value increase $\left(\mathrm{R}^{2}=.668\right)$. Thus, the fifth hypothesis is supported in the Saudi Arabian context.

Test of $\mathrm{H}_{6}$ There is a significant effect of Market Value adoption on Market Capitalization in Tourism and Hotels Index in Saudi Arabian Stock Exchange.

Table 11: Saudi Arabian Stock Exchange percentage exchange between (Market Value - Market Capitalization) for Tourism and Hotels Index Firms during the Period 2010 : 2018

\begin{tabular}{|l|c|c|c|c|}
\hline Tourism and Hotels Index firms & Market Value & Market & Market & $\%(2010:$ \\
& Change Rate \% & Capitalization & Capitalization & $2018)$ \\
\hline
\end{tabular}


International Journal of Heritage, Tourism and Hospitality Vol. (13), No. (1), March, 2019 By: Faculty of Tourism and Hotels, Fayoum University

\begin{tabular}{|c|c|c|c|c|}
\hline Altayyar Travel Group & $43.4 \%$ & 80000000 & 5304145000 & $6530.20 \%$ \\
\hline Alkhaleej Training and Education Co. & $27.9 \%$ & 202500000 & 679500000 & $235.60 \%$ \\
\hline Herfy Food Services Co. & $60.3 \%$ & 828900000 & 2955876000 & $256.60 \%$ \\
\hline
\end{tabular}

Accordingly, it is obvious from table (11) that Market Value works to increase Market Capitalization like: Altayyar Travel Group that indicates 6530.2\%, Alkhaleej Training and Education Co. that indicates 235.6\%, Herfy Food Services Co that indicates 256.6\%. Which proves to us that, Market Value works to increase Market Capitalization and encourages small investors to invest in Tourism and Hotels Index and attract more investors to finance in tourism and hospitality projects and future company's investment plans.

Table 12: Saudi Stock Exchange between (Market Value - Market Capitalization) results of

\begin{tabular}{|c|c|c|c|c|c|c|}
\hline \multicolumn{1}{|c|}{ Regression analysis } \\
\hline & $\mathrm{R}^{2}$ & $\mathrm{~F}$ & $\mathrm{~B}$ & Std. Error & $\mathrm{T}$ & Sig. \\
\hline Constant & .922 & 23.673 & .110 & .083 & 1.337 & .313 \\
\hline Market Capitalization & & & 4.462 & .917 & 4.866 & .040 \\
\hline
\end{tabular}

Table (12) illustrates the statistics of linear regression calculated to measure the impact of Market Value on Market Capitalization. It is revealed that, (B value $=4.462$ ), $\mathrm{P}<0.01$. A significant positive effect of Market Value on Market Capitalization was found in the Saudi context. It is revealed that Market Value is explaining 92.2\% of Market Capitalization increase $\left(\mathrm{R}^{2}=.922\right)$. Thus, the sixth hypothesis is supported in the Saudi context.

\section{Test of $\mathrm{H}_{7}$ There is a significant effect of Stock Split adoption on Market Capitalization in Hotels and Tourism Index in Bahrain Bourse.}

Table 13: Bahrain Bourse percentage exchange (Stock Split - Market Capitalization) for Tourism and Hospitality Index during the period $2010: 2018$

\begin{tabular}{|c|c|c|c|c|c|c|}
\hline $\begin{array}{c}\text { Hotels and Tourism } \\
\text { Index Firms }\end{array}$ & $\begin{array}{c}\text { Shares } \\
2010\end{array}$ & $\begin{array}{c}\text { Shares } \\
2018\end{array}$ & $\begin{array}{c}\% \\
(2010: \\
2018)\end{array}$ & $\begin{array}{c}\text { Market } \\
\text { Cap. } \\
2010\end{array}$ & $\begin{array}{c}\text { Market } \\
\text { Cap. } \\
2018\end{array}$ & $\begin{array}{c}\%(2010 \\
: 2018)\end{array}$ \\
\hline $\begin{array}{c}\text { Bahrain Family } \\
\text { Leisure }\end{array}$ & 36000000 & 40000000 & $11 \%$ & 3960000 & 3200000 & $-19.2 \%$ \\
\hline $\begin{array}{c}\text { Gulf Hotel Group } \\
\text { B.S.C. }\end{array}$ & 165338510 & 225994863 & $37 \%$ & 84322640.1 & 112997431.5 & $\% 34$ \\
\hline $\begin{array}{c}\text { National Hotels } \\
\text { company }\end{array}$ & 100000000 & 110250000 & $10 \%$ & 40400000 & 110250000 & $173 \%$ \\
\hline
\end{tabular}

Accordingly, it is obvious from table (13) that Stock Split works to increase Market Capitalization like: Gulf Hotel Group B.S.C. that indicates 34\%, and National Hotels Company that indicates $173 \%$. This point is supported by the study conducted by Huang et al., (2011), Waweru et al., (2012); Nyaga, (2017), Elgarhy et al., (2015a), Elgarhy et al., (2017b), El Ansary and Hussien (2017), Salama (2017). Which proves to us that, Stock Split works to increase Market Capitalization and encourages small investors to invest in Hotels and Tourism Index and attract more investors to finance in tourism and hospitality projects and future company's investment plans. 
Table 14: Bahrain Bourse between (Stock Split - Market Capitalization) results of regression analysis

\begin{tabular}{|c|c|c|c|c|c|c|}
\hline & $\mathrm{R}^{2}$ & $\mathrm{~F}$ & $\mathrm{~B}$ & Std. Error & $\mathrm{T}$ & Sig. \\
\hline Constant & .356 & 18.765 & $-1.401 \mathrm{E}-6$ & $1.618 \mathrm{E} 7$ & $-.519-$ & .607 \\
\hline Market Capitalization & & & .537 & .124 & 4.332 & .000 \\
\hline
\end{tabular}

Table (14) illustrates the statistics of linear regression calculated to measure the impact of Stock Split on Market Capitalization. It is revealed that, $(\mathrm{B}$ value $=.537), \mathrm{P}<0.01$. A significant positive effect of Stock Split on Market Capitalization was found in the Bahrain context. It is revealed that Stock Split is explaining 35.6\% of Market Capitalization increase $\left(\mathrm{R}^{2}=.356\right)$. Thus, the seventh hypothesis is supported in the Bahrain context.

\section{Test of $\mathbf{H}_{8}$ There is a significant effect of Stock Split adoption on Market Value in Hotels and Tourism Index in Bahrain Bourse.}

Table 15: Bahrain Bourse percentage exchange between (Stock Split - Market Value Change Rate) for Hotels and Tourism Index during the Period $2010: 2018$

\begin{tabular}{|c|c|c|c|c|}
\hline $\begin{array}{c}\text { Hotels and Tourism Index } \\
\text { firms }\end{array}$ & $\begin{array}{c}\text { Shares } \\
2010\end{array}$ & $\begin{array}{c}\text { Shares } \\
2018\end{array}$ & $\begin{array}{c}\%(2010: \\
2018)\end{array}$ & $\begin{array}{c}\text { Market Value } \\
\text { Change Rate \% } \\
(2010: 2018)\end{array}$ \\
\hline Bahrain Family Leisure & 36000000 & 40000000 & $11 \%$ & $70.9 \%$ \\
\hline Gulf Hotel Group B.S.C. & 165338510 & 225994863 & $37 \%$ & $54.4 \%$ \\
\hline National Hotels company & 100000000 & 110250000 & $10 \%$ & $8.4 \%$ \\
\hline
\end{tabular}

Accordingly, it is obvious from table (15) that Stock Split works to increase Market Value like: Bahrain Family Leisure that indicates 70.9\%, Gulf Hotel Group B.S.C. that indicates 54.4\%, and National Hotels Company that indicates $8.4 \%$. This point is supported by the study conducted by Bandyopadhyay et al., (2010); Huang et al., (2011), Waweru et al., (2012); Tabibian (2013); Agara, (2014); Chowdhury (2014); Nyaga, (2017). Which proves to us that, Stock Split works to increase Market Value and encourages investors to invest in Hotels and Tourism Index and attract more investors to finance in tourism and hospitality projects and future company's investment plans.

Table 16: Bahrain Bourse between (Stock Split - Market Value) results of regression analysis

\begin{tabular}{|c|c|c|c|c|c|c|}
\hline & $\mathrm{R}^{2}$ & $\mathrm{~F}$ & $\mathrm{~B}$ & Std. Error & $\mathrm{T}$ & Sig. \\
\hline Constant & .994 & 173.211 & -8.643 & 1.537 & -5.625 & .112 \\
\hline Market Value & & & 130.804 & 9.939 & 13.161 & .048 \\
\hline
\end{tabular}

Table (16) illustrates the statistics of linear regression calculated to measure the impact of Stock Split on Market Value. It is revealed that, $(\mathrm{B}$ value $=130.804), \mathrm{P}<0.01$. A significant positive effect of Stock Split on Market Value was found in the Bahrain context. It is revealed that Stock Split is explaining $99.4 \%$ of Market Value increase $\left(\mathrm{R}^{2}=.994\right)$. Thus, the eighth hypothesis is supported in the Bahrain context. 
International Journal of Heritage, Tourism and Hospitality Vol. (13), No. (1), March, 2019

By: Faculty of Tourism and Hotels, Fayoum University

Test of $\mathrm{H}_{9}$ There is a significant effect of Market Value adoption on Market Capitalization in Hotels and Tourism Index in Bahrain Bourse.

Table 17: Bahrain Bourse percentage exchange between (Market Value - Market Capitalization) for Tourism and Hospitality Index Firms during the period $2010: 2018$

\begin{tabular}{|c|c|c|c|c|}
\hline Hotels and Tourism Index Firms & $\begin{array}{c}\text { Market Value } \\
\text { Change Rate } \% \\
(2010: 2018)\end{array}$ & $\begin{array}{c}\text { Market } \\
\text { Capitalization } \\
2010\end{array}$ & $\begin{array}{c}\text { Market } \\
\text { Capitalization } \\
2018\end{array}$ & $\begin{array}{c}\% \\
(2010: \\
2018)\end{array}$ \\
\hline Bahrain Family Leisure & $70.9 \%$ & 3960000 & 3200000 & $-19.2 \%$ \\
\hline Gulf Hotel Group B.S.C. & $54.4 \%$ & 84322640.1 & 112997431.5 & $\% 34$ \\
\hline National Hotels company & $8.4 \%$ & 40400000 & 110250000 & $173 \%$ \\
\hline Banader Hotels Company BSC & $1.8 \%$ & 10500000 & 150000000 & $1329.6 \%$ \\
\hline
\end{tabular}

Accordingly, it is obvious from table (17) that Market Value works to increase Market Capitalization like: Gulf Hotel Group B.S.C. that indicates 34\%, National Hotels Company that indicates $173 \%$, and Banader Hotels Company BSC that indicates $1328 \%$. Which proves to us that, Market Value works to increase Market Capitalization and encourages small investors to invest in Hotels and Tourism Index and attract more investors to finance in tourism and hospitality projects and future company's investment plans.

Table 18: Bahrain Bourse between (Market Value - Market Capitalization) results of regression analysis

\begin{tabular}{|c|c|c|c|c|c|c|}
\hline & $\mathrm{R}^{2}$ & $\mathrm{~F}$ & $\mathrm{~B}$ & Std. Error & $\mathrm{T}$ & Sig. \\
\hline Constant & .996 & 238.331 & .482 & $1.618 \mathrm{E} 7$ & 5.116 & .123 \\
\hline Market Capitalization & & & .104 & .124 & 15.438 & .041 \\
\hline
\end{tabular}

Table (18) illustrates the statistics of linear regression calculated to measure the impact of Market Value on Market Capitalization. It is revealed that, $(\mathrm{B}$ value $=.104), \mathrm{P}<0.01$. A significant positive effect of Market Value on Market Capitalization was found in the Bahrain context. It is revealed that Market Value is explaining 99.6\% of Market Capitalization increase $\left(\mathrm{R}^{2}=.996\right)$. Thus, the ninth hypothesis is supported in the Bahrain context.

Table 19: Total Shares, Total Market Value, and Total Market Capitalization for Hospitality and Tourism Index's in the three Bourses

\begin{tabular}{|l|c|c|c|c|c|c|c|c|c|}
\hline \multirow{2}{*}{} & \multicolumn{3}{|c|}{$\begin{array}{c}\text { The Egyptian } \\
\text { Exchange (EGP) }\end{array}$} & \multicolumn{3}{c|}{$\begin{array}{c}\text { Saudi Arabian Stock } \\
\text { Exchange (SAR) }\end{array}$} & \multicolumn{2}{c|}{ Bahrain Bourse (BHD) } \\
\cline { 2 - 10 } & 2010 & 2018 & $\begin{array}{c}\% \\
2010- \\
2018\end{array}$ & 2010 & 2018 & $\begin{array}{c}\% \\
2010- \\
2018\end{array}$ & 2010 & 2018 & $\begin{array}{c}\% \\
2010- \\
2018\end{array}$ \\
\hline $\begin{array}{l}\text { Total Shares } \\
\text { (Million) }\end{array}$ & 2.4 & 2.9 & $20.8 \%$ & 639.9 & 484.5 & $-24.3 \%$ & 451.3 & 526.2 & $16.6 \%$ \\
\hline $\begin{array}{l}\text { Total Market } \\
\begin{array}{l}\text { Value } \\
\text { (Hundred) }\end{array}\end{array}$ & 136 & 753 & $453.7 \%$ & 90 & 159 & $76.6 \%$ & 1 & 1 & - \\
\hline $\begin{array}{l}\text { Total Market } \\
\begin{array}{l}\text { Capitalization } \\
\text { (Billion) }\end{array}\end{array}$ & 21.8 & 24.7 & $13.3 \%$ & 3.7 & 12.4 & $235.1 \%$ & .138 .8 & .376 .4 & $171.2 \%$ \\
\hline
\end{tabular}

The findings presented in table (19) show Total Shares, Total Market Value, and Total Market Capitalization in Hospitality and Tourism Index's for the Egyptian Exchange, Saudi Arabian 
Stock Exchange, and Bahrain Bourse during the period 2010 - 2018. The Egyptian Exchange, Total Shares at the end of the year 2018 reached 2.9 million shares increased by $20.8 \%$ compare to 2010 reached 2.4 million shares. The Total Market Value at the end of the year 2018 reached Market Value EGP 753 thousand increased by 453.7\% compare to 2010 reached Market Value EGP 136 thousand. The Total Market Capitalization at the end of the year 2018 reached EGP 28.7 billion increased by $13.3 \%$ compare to 2010 reached EGP 21.8 billion. Saudi Arabian Stock Exchange, Total Shares at the end of the year 2018 reached 484.5 million shares decreased by 24.3\% compare to 2010 reached 639.9 million shares. The Total Market Value at the end of the year 2018 reached Market Value SAR 159 thousand increased by 76.6\% compare to 2010 reached Market Value SAR 90 thousand. The Total Market Capitalization at the end of the year 2018 reached SAR 12.4 billion increased by $235.1 \%$ compare to 2010 reached SAR 3.7 billion. Bahrain Bourse, Total Shares at the end of the year 2018 reached 526.2 million shares increased by $16.6 \%$ compare to 2010 reached 451.3 million shares. The Total Market Capitalization at the end of the year 2018 reached BHD 376.3 Million increased by $171.2 \%$ compare to 2010 reached BHD 138.8 Million.

\section{Discussion of Findings}

$\mathrm{H}_{1}$ the finding revealed measure the effect of Stock Split on Market Capitalization. It is revealed that, $(\mathrm{B}$ value $=2.346$ ), $\mathrm{P}<0.01$. A significant positive effect of Stock split on Market Capitalization was found in the Egyptian context. It is revealed that Stock Split is explaining $14.7 \%$ of Market Capitalization increase $\left(\mathrm{R}^{2}=.147\right)$ with a significant $(.000)$ which is lower than the level of statistical significance $(\alpha=0.05)$, which indicates that we could not reject the null hypothesis in favor of the alternative hypothesis, which that: "There is a significant effect of Stock Split adoption on Market Capitalization in Travel and Leisure Index in the Egyptian Exchange". Thus, the first hypothesis is supported in the Egyptian context.

$\mathrm{H}_{2}$ the finding revealed measure the effect of Stock Split on Market Value. It is revealed that, (B value $=1.619), \mathrm{P}<0.01$. A significant positive effect of Stock Split on Market Value was found in the Egyptian context. It is revealed that Stock Split is explaining $70.3 \%$ of Market Value increase $\left(\mathrm{R}^{2}=.703\right)$ With a significant $(.037)$ which is lower than the level of statistical significance $(\alpha=0.05)$, which indicates that we could not reject the null hypothesis in favor of the alternative hypothesis, which that: "There is a significant effect of Stock Split adoption on Market Value in Travel and Leisure Index in the Egyptian Exchange". Thus, the second hypothesis is supported in the Egyptian context.

$\mathrm{H}_{3}$ the finding revealed measure the effect of Market Value on Market Capitalization. It is revealed that, $(\mathrm{B}$ value $=.126), \mathrm{P}<0.01$. A significant positive effect of Market Value on Market Capitalization was found in the Egyptian context. It is revealed that Market Value is explaining $77.8 \%$ of Market Capitalization increase $\left(\mathrm{R}^{2}=.778\right)$ With a significant $(.048)$ which is lower than the level of statistical significance $(\alpha=0.05)$, which indicates that we could not reject the null hypothesis in favor of the alternative hypothesis, which that: "There is a significant effect of Market Value adoption on Market Capitalization in Travel and Leisure Index in the Egyptian Exchange". Thus, the third hypothesis is supported in the Egyptian context.

$\mathrm{H}_{4}$ the finding revealed measure the impact of Stock Split on Market Capitalization. It is revealed that, $(\mathrm{B}$ value $=9.587), \mathrm{P}<0.01$. A significant positive effect of Stock Split on Market Capitalization was found in the Saudi context. It is revealed that Stock Split is explaining 8.2\% of Market Capitalization increase $\left(\mathrm{R}^{2}=.082\right)$ with a significant $(.035)$ which is lower than the 
level of statistical significance $(\alpha=0.05)$, which indicates that we could not reject the null hypothesis in favor of the alternative hypothesis, which that: "There is a significant effect of Stock Split adoption on Market Capitalization in Tourism and Hotels Index in Saudi Arabian Stock Exchange". Thus, the forth hypothesis is supported in the Saudi context.

$\mathrm{H}_{5}$ the finding revealed measure the impact of Stock Split on Market Value. It is revealed that, (B value $=.134), \mathrm{P}<0.01$. A significant positive effect of Stock Split on Market Value was found in the Saudi context. It is revealed that Stock Split is explaining 66.8\% of Market Value increase $\left(\mathrm{R}^{2}=.668\right)$. With a significant (.047) which is lower than the level of statistical significance $(\alpha=$ 0.05), which indicates that we could not reject the null hypothesis in favor of the alternative hypothesis, which that: "There is a significant effect of Stock Split adoption on Market Value in Tourism and Hotels Index in Saudi Arabian Stock Exchange". Thus, the fifth hypothesis is supported in the Saudi Arabian context.

$\mathrm{H}_{6}$ the finding revealed measure the impact of Market Value on Market Capitalization. It is revealed that, $(\mathrm{B}$ value $=4.462), \mathrm{P}<0.01$. A significant positive effect of Market Value on Market Capitalization was found in the Saudi context. It is revealed that Market Value is explaining 92.2\% of Market Capitalization increase $\left(\mathrm{R}^{2}=.922\right)$. With a significant $(.040)$ which is lower than the level of statistical significance $(\alpha=0.05)$, which indicates that we could not reject the null hypothesis in favor of the alternative hypothesis, which that: "There is a significant effect of Market Value adoption on Market Capitalization in Tourism and Hotels Index in Saudi Arabian Stock Exchange". Thus, the sixth hypothesis is supported in the Saudi context.

$\mathrm{H}_{7}$ the finding revealed measure the effect of Stock Split on Market Capitalization. It is revealed that, $(\mathrm{B}$ value $=.537), \mathrm{P}<0.01$. A significant positive effect of Stock Split on Market Capitalization was found in the Bahrain context. It is revealed that Stock Split is explaining $35.6 \%$ of Market Capitalization increase $\left(\mathrm{R}^{2}=.356\right)$ with a significant $(.000)$ which is lower than the level of statistical significance $(\alpha=0.05)$, which indicates that we could not reject the null hypothesis in favor of the alternative hypothesis, which that: "There is a significant effect of Stock Split adoption on Market Capitalization in Hotels and Tourism Index in Bahrain Bourse". Thus, the seventh hypothesis is supported in the Bahrain context.

$\mathrm{H}_{8}$ the finding revealed measure the effect of Stock Split on Market Value. It is revealed that, (B value $=130.804), \mathrm{P}<0.01$. A significant positive effect of Stock Split on Market Value was found in the Bahrain context. It is revealed that Stock Split is explaining 99.4\% of Market Value increase $\left(\mathrm{R}^{2}=.994\right)$ With a significant $(.048)$ which is lower than the level of statistical significance $(\alpha=0.05)$, which indicates that we could not reject the null hypothesis in favor of the alternative hypothesis, which that: "There is a significant effect of Stock Split adoption on Market Value in Hotels and Tourism Index in Bahrain Bourse". Thus, the eighth hypothesis is supported in the Bahrain context.

$\mathrm{H}_{9}$ the finding revealed measure the effect of Market Value on Market Capitalization. It is revealed that, $(\mathrm{B}$ value $=.104), \mathrm{P}<0.01$. A significant positive effect of Market Value on Market Capitalization was found in the Bahrain context. It is revealed that Market Value is explaining $99.6 \%$ of Market Capitalization increase $\left(\mathrm{R}^{2}=.996\right)$ With a significant $(.041)$ which is lower than the level of statistical significance $(\alpha=0.05)$, which indicates that we could not reject the null hypothesis in favor of the alternative hypothesis, which that: "There is a significant effect of Market Value adoption on Market Capitalization in Hotels and Tourism Index in Bahrain Bourse". Thus, the ninth hypothesis is supported in the Bahrain context. 


\section{Conclusions}

The present study aims to investigate the effect of Stock Split on Market Capitalization, Market Value, and effect of Market Value on Market Capitalization in Hospitality and Tourism in three Bourses. For the purpose of the study, determination of whether Stock Split made by Hospitality and Tourism Sector Index's firms in the Egyptian Exchange, Saudi Arabian Stock Exchange and Bahrain Bourse has an effect on the splitting firms. The study uses historical quantitative data in the period (2010 to 2018) collected from Egyptian Exchange, Saudi Arabian Stock Exchange, Bahrain Bourse, to follow the deductive approach, to test the study hypotheses and accomplish its objectives. Based on linear regression analysis, the finding revealed there is a significant positive relationship between the effects of Stock Split on Market Capitalization in three Bourses. In addition, Market Capitalization is effecting by stock Split, and effect of Market Value on Market Capitalization in hospitality and tourism sector Index's in the Egyptian Exchange, Saudi Arabian Stock Exchange, and Bahrain Bourse. To conclude, Stock Split works to increase Market Capitalization, Market Value and encourages small investors to invest in Hotels and Tourism Index and attract more investors to finance in tourism and hospitality projects and future company's investment plans. As many market participants, including small investors, think the share is now more affordable and buy the share, this can enhance the demand and drive up the price.

\section{References}

Abdolmohammadi, M. J., (2005), "Intellectual Capital Disclosure and Market Capitalization", Journal of Intellectual Capital, Vol. 6 No. 3, pp. 397-416.

Abeysekera, I. (2011), "The relation of intellectual capital disclosure strategies and market value in two political settings", Journal of Intellectual Capital, Vol. 12 No. 2, pp.319-38.

Agara, B., (2014), "The Effect of Stock Split on Share Price of Companies Listed at the Nairobi Securities Exchange", Master of Science in Finance and Accounting, School of Business, University of Nairobi.

Amadeo, K., (2016), access at https:// www.thebalanc.com, 20/11/2017, 09:56 pm.

Anam, O. A., Fatima, A., Majdi, A. H., (2011) "Effects of Intellectual Capital Information Disclosed in Annual Reports on Market Capitalization: Evidence from Bursa Malaysia", Journal of Human Resource Costing \& Accounting, Vol. 15 Issue: 2, pp.85-101, https:// doi.org/10.1108/14013381111157328.

Bahrain Bourse, (2018), "Bahrain Bourse Annual Report", available at, http://www.bahrainbourse.com/annual-report.

Bandyopadhyay, P., Hackard, T., Tse, Y., (2010) "The Effect of Stock Splits on IShare Exchange-traded Funds", Managerial Finance, Vol. 36 Issue: 2, pp.134-159, https:// doi.org/10.1108/03074351011014550.

Barrows, C.W., \& Naka, A., (1994), "Use of Macroeconomic Variables to Evaluate Selected Hospitality Stock Returns in the US", International Journal of Hospitality Management 13, pp.119-128.

Borghesi, R. Annaraud, K., Singh, D. (2015), "Are Hospitality Industry IPO Stock Returns Predictable?", International Journal of Hospitality Management 44 pp. 23-27, http://dx.doi.org/10.1016/j.ijhm.2014.09.007.

Borghesi, R. Annaraud, K., Singh, D. (2015), "Are Hospitality Industry IPO Stock Returns Predictable?", International Journal of Hospitality Management 44 pp. 23-27, http://dx.doi.org/10.1016/j.ijhm.2014.09.007. 
Chen, M. H., (2007b), "The Impact of Macroeconomic and Non-macroeconomic Forces on Hotel Stock Returns", Hospitality Management, 26, pp. 588-602 www.elsevier.com/locate/ijhosman.

Chen, M. H., Kim, W.G., Kim, H.J., (2005), "The Impact of Macroeconomic and NonMacroeconomic Forces on Hotel Stock Returns", International Journal of Hospitality Management 24, pp. 243-258.

Chen, M., H., (2013a), "Asymmetric Response of Hospitality Stock Prices to Fed Policy Actions", International Journal of Hospitality Management, 33, pp. 129-139, http://dx.doi.org/10.1016/j.ijhm.2012.07.006.

Chowdhury, M. N. H., (2014), "The Effect of Large Stock Split announcements on Price of U.S. High Technology Stocks”, Master of Finance, Saint Mary's University.

El Ansary, O., and Hussien, M., (2017), "The Impact of Stock dividends and Stock Splits on Shares Prices: Evidence from Egypt", Accounting and Finance Research, Vol. 6, No. 4, http://afr.sciedupress.com.

Elgarhy, S., Fayed, H., \& Abou-Shouk, M. (2017), "Relationship between Leisure Sector Investments and Food and Beverage in the Egyptian Stock Market", International Journal of Heritage, Tourism, and Hospitality, 11(3/1).

Elgarhy, S., Fayed, H., Kasim, A., \& Abou-Hamad, M. (2015), "Capital market and the Tourism Performance in Egypt - Analytical Study for the Current Situation", International Journal of Heritage, Tourism, And Hospitality, 9(2/1).

Eltony, M., N., Babiker, M., (2005), "Arab Capital Markets Development and Institutions", Journal of Economic and Administrative Sciences, Vol. 21 Issue: 1, pp.42-63, https://doi.org/10.1108/10264116200500002.

Faure, Pa. (2013b), "Financial System: An Introduction" 1st edition, Quoin Institute (Pty) Limited \& bookboon.com, ISBN 978-87-403-0592-0.

Faure, Pa. (2015a), "Financial Institution: An Introduction" 1st edition, Quoin Institute (Pty) Limited \& bookboon.com, ISBN 978-87-403-0886 0.

Financial Statement (2010/2011/2012/2013/2014/2015/2016/2017/2018), "Sharm Dreams Co. For Tourism Investment", Egyptian joint stock company, The Egyptian Exchange.

Financial Statement(2010/2011/2012/2013/2014/2015/2016/2017/2018), "Gulf Hotel Group B.S.C.", Bahrain joint stock company, Bahrain Bourse.

Financial Statement, (2010/2011/2012/2013/2014/2015/2016/2017/2018), "Orascom Development Egypt", Egyptian joint stock Company, The Egyptian Exchange.

Financial Statement, (2010/2011/2012/2013/2014/2015/2016/2017/2018), "Rowad Misr Tourism Investment, Egyptian joint stock Company", The Egyptian Exchange.

Financial Statement, (2010/2011/2012/2013/2014/2015/2016/2017/2018), "Trans Oceans Tours", Egyptian joint stock company, The Egyptian Exchange.

Financial Statement, (2010/2011/2012/2013/2014/2015/2016/2017/2018), "El Wadi Co. For Touristic Investment", Egyptian joint stock company, The Egyptian Exchange.

Financial Statement, (2010/2011/2012/2013/2014/2015/2016/2017/2018), "Egyptian International Tourism Projects", Egyptian joint stock company, The Egyptian Exchange.

Financial Statement, (2010/2011/2012/2013/2014/2015/2016/2017/2018), "Rowad Tourism (A1 Rowad)", Egyptian joint stock company, The Egyptian Exchange.

Financial Statement, (2010/2011/2012/2013/2014/2015/2016/2017/2018), "Pyramisa Hotels", Egyptian joint stock company, Egyptian Exchange. 
Financial Statement, (2010/2011/2012/2013/2014/2015/2016/2017/2018), "Egyptian for Tourism

Resorts", Egyptian joint stock company, Egyptian Exchange.

Financial Statement, (2010/2011/2012/2013/2014/2015/2016/2017/2018), "Sky Light for Tourist

Development Company", Egyptian joint stock company, The Egyptian Exchange.

Financial Statement, (2010/2011/2012/2013/2014/2015/2016/2017/2018), "Marsa Marsa Alam for Tourism Development", Egyptian joint stock company, The Egyptian Exchange.

Financial Statement, (2010/2011/2012/2013/2014/2015/2016/2017/2018), "Golden Coast Company", Egyptian joint stock company, The Egyptian Exchange.

Financial Statement, (2010/2011/2012/2013/2014/2015/2016/2017/2018), "Altayyar Travel Group", Saudi joint stock company, Saudi Stock Exchange.

Financial Statement, (2010/2011/2012/2013/2014/2015/2016/2017/2018), "Abdul Mohsen Alhokair Group for Tourism \& Development", Egyptian joint stock company, Saudi Stock Exchange.

Financial Statement, (2010/2011/2012/2013/2014/2015/2016/2017/2018), "Dur Hospitality Company", Egyptian joint stock company, Saudi Stock Exchange.

Financial Statement, (2010/2011/2012/2013/2014/2015/2016/2017/2018), "Tourism Enterprise

Co. (Shams)", Saudi joint stock company, Saudi Stock Exchange.

Financial Statement, (2010/2011/2012/2013/2014/2015/2016/2017/2018), Exchange.

Financial Statement, (2010/2011/2012/2013/2014/2015/2016/2017/2018), "Herfy Food Services Co.", Saudi joint stock company, Saudi Stock Exchange.

Financial Statement, (2010/2011/2012/2013/2014/2015/2016/2017/2018), "Bahrain Family Leisure", Saudi joint stock company, Bahrain Bourse.

Financial Statement, (2010/2011/2012/2013/2014/2015/2016/2017/2018), "Banader Hotels Company BSC", Bahrain joint stock company, Bahrain Bourse.

Financial Statement, (2010/2011/2012/2013/2014/2015/2016/2017/2018), "National Hotels Company", Bahrain joint stock company, Bahrain Bourse.

Financial Statement, (2010:2018), "Golden Pyramids Plaza", Egyptian joint stock company, Egyptian Exchange.

Financial Statement, (2010:2018), "Remco for Touristic Villages Construction", Egyptian joint stock Company, The Egyptian Exchange.

Financial Statement, (2010:2018),"El Shams Pyramids for Hotels \& Touristic Projects", Egyptian joint stock Company, The Egyptian Exchange.

Financial Statement, (2010:2018),"Misr Hotels", Egyptian joint stock company, Egyptian Exchange.

Gu, Z. (1994), "Hospitality Investment Returns, Risk, And Performance Indexes: A Ten Year Examination", Hospitality Research Journal, Vol. 17, Number 3.

Huang, G.C., Liano k. \& Pan M. S. (2011), "REIT Stock Splits and Liquidity Changes", Journal of Real Estate Finance \& Economics, https://link.springer.com/article/10.1007/s11146009-9222-y.

Jang, S. \& Park, K., (2011),"Hospitality Finance Research During Recent Two Decades", International Journal of Contemporary Hospitality Management, Vol. 23 Iss 4 pp. 479 497.

Nicolau, J., L., \& Santa-Maria, M., J., (2013), "The Effect of Innovation on Hotel Market Value", International Journal of Hospitality Management, 32, pp. 71-79. 
Nyaga, P, N., (2017), “The effect of Stock Split Announcements on Share Price of Companies Listed at The Nairobi Securities exchange", Master of Science in Finance and Accounting, School of Business, University of Nairobi.

Orens, R., Aerts, W. and Lybaert, N. (2009), "Intellectual Capital Disclosure, Cost of Fnance and Firm Value", Management Decision, Vol. 47 No. 10, pp. 1536-54.

Park. K., \& Jang, S., S., (2014), "Hospitality Finance and Managerial Accounting Research", International Journal of Contemporary Hospitality Management, Vol. 26 Iss 5 pp. 751 777 http://dx.doi.org/10.1108/IJCHM-12-2013-0554.

Petersen, L., W., (2017), "Introduction to Investment and Finance", 1st edition, Peer review by Mark Leslie Hughes, Erhvervsakademi Aarhus, Denmark, ISBN 978-87-403-1646-9.

Salama, M., (2017), "The Effect of Stock Split Policy on Stock Prices Returns", trading volume and prices' Volatility in the Egyptian stock market - An applied study, Faculty of Commerce, Ain Shams University.

Saudi Stock Exchange, (2017), "Tadawul Annual Statistical Report", available at https:// www.tadawul.com.sa /wps/portal/tadawul/markets /reports-\%26-publications/periodicalpublications.

Spagat, M., \& Dougherty, J., (2010), "Conflict Deaths in Iraq: A Methodological Critique of the ORB Survey Estimate", Survey Research Methods, pp. 3-15.

Steve Pan, H., T., \& Lee, J., (2011), "Recent Research in Hospitality Financial Management", International Journal of Contemporary Hospitality Management, Vol. 23 Iss 7 pp. 941 971, http://dx.doi.org/10.1108/09596111111167542.

Tabibian, S, A., (2013), "The Effect of Stock Split on Stock Return: Evidence from Malaysia", 261988450_The_Effect_of_Stock_Split_on_Stock_Return_Evidence_from_Malaysia.

Tasi, H., Pan, S. and Lee, J. (2011), "Recent Research in Hospitality Financial Management", International Journal of Contemporary Hospitality Management, Vol. 23 No. 7, pp. 941 971.

The Egyptian Exchange, (2010/2011/2012/2013/2014/2015/2016/2017/2018), "The Egyptian Exchange Annual" Report, Available at http://www.egx.com.eg/en/services_reports.aspx.

The Egyptian Exchange, (2018), "The Egyptian Exchange Annual" Report, Available at http://www.egx.com.eg/en/services_reports.aspx.

Thomas, S. L., \& Heck, R. H., (2001), "Analysis of Large-scale Secondary Data in Higher Education Research: Potential Perils Associated with Complex Sampling Designs", Research in Higher Education, 42, 517-540.

Trzesniewski, K. H., Donnellan, M. B., \& Lucas, R. E., (Eds) (2011), "Secondary Data Analysis: An Introduction for Psychologists", Washington, D.C.: APA.

Vartanian, T. P. (2011), "Secondary Data Analysis", New York, NY: Oxford.

Waweru, N.M., \& Mwendwa, J. (2012), "Stock Splits and Their Effect on Share Prices: A Study of firms Listed on The Nairobi Stock Exchange (NSE)", Academy of Accounting and Financial Studies Journal, 16 (2). 